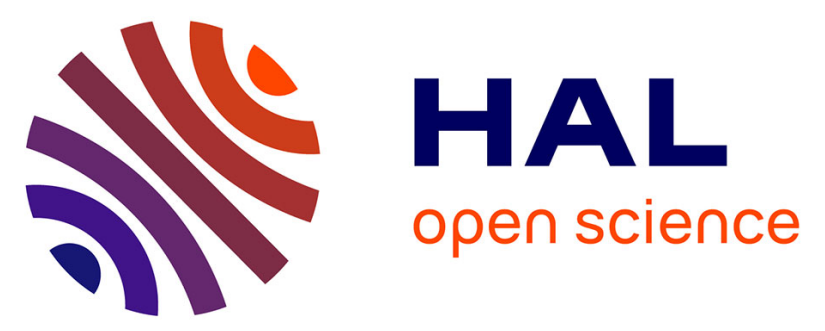

\title{
Isolation of growth hormone and in vitro translation of mRNA isolated from pituitaries of the gilthead sea bream Sparus aurata
}

B. Cavari, Pierre-Yves Le Bail, B. Levavi-Sivan, P. Melamed, H. Kawauchi, B.

Funkenstein

\section{To cite this version:}

B. Cavari, Pierre-Yves Le Bail, B. Levavi-Sivan, P. Melamed, H. Kawauchi, et al.. Isolation of growth hormone and in vitro translation of mRNA isolated from pituitaries of the gilthead sea bream Sparus aurata. General and Comparative Endocrinology, 1994, 95, pp.321-329. 10.1006/gcen.1994.1129 . hal-02713421

\section{HAL Id: hal-02713421 \\ https://hal.inrae.fr/hal-02713421}

Submitted on 1 Jun 2020

HAL is a multi-disciplinary open access archive for the deposit and dissemination of scientific research documents, whether they are published or not. The documents may come from teaching and research institutions in France or abroad, or from public or private research centers.
L'archive ouverte pluridisciplinaire HAL, est destinée au dépôt et à la diffusion de documents scientifiques de niveau recherche, publiés ou non, émanant des établissements d'enseignement et de recherche français ou étrangers, des laboratoires publics ou privés. 


\title{
Isolation of Growth Hormone and in Vitro Translation of mRNA Isolated from Pituitaries of the Gilthead Sea Bream Sparus aurata
}

\author{
B. Cavari, ${ }^{*}$ P.-Y. Le Bail,$\dagger$ B. Levavi-Sivan,$\ddagger$ P. Melamed,$\ddagger$ H. Kawauchi,$\S$ \\ AND B. FUNKENSTEIN*
}

\begin{abstract}
${ }^{*}$ National Institute of Oceanography, Israel Oceanographic \& Limnological Research, Tel Shikmona, Haifa 31080, Israel; †Laboratoire de Physiologie des Poissons (INRA), Campus de Beaulieu, 35042 Rennes Cedex, France; $¥$ Department of Zoology, Tel-Aviv University, Tel-Aviv, Israel; and \$Laboratory of Molecular Endocrinology, School of Fisheries Sciences, Kitasato University, Sanriku, Iwate, Japan
\end{abstract}

Accepted March 22, 1994

\begin{abstract}
Growth hormone $(\mathrm{GH})$ polypeptide was purified from pituitary glands of the gilthead sea bream (Sparus aurata) by a two-step procedure involving gel filtration on Sephadex G-100 and reverse-phase high-performance liquid chromatography (гpHPLC). At each stage of purification, fractions were monitored by SDS-polyacrylamide gel electrophoresis (SDS$P A G E$ ) and by immunoblotting using anti-bonito $G H$ antiserum. The molecular weight of the sea bream GH was estimated by SDS-PAGE to be $21 \mathrm{kDa}$ when electrophoresed in the absence of $\beta$-mercaptoethanol (nonreduced conditions) and $22 \mathrm{kDa}$ when electrophoresed under reduced conditions (in the presence of $1 \% \beta$-mercaptoethanol). Pituitary RNA was used to direct cell-free translation. When specific immunoisolation from ${ }^{35} \mathrm{~S}$-labeled proteins was conducted, using antisera against Sparus or tilapia GH, a larger prehormone was immunoprecipitated. The size of the pre-GH was estimated to be $27-28 \mathrm{kDa}$ under reduced conditions and 26-27 kDa under nonreduced conditions, in agreement with the calculated molecular weight of Sparus pre-GH of 26,296 based on the deduced amino acid sequence of Sparus GH cDNA. The specificity of the immunoprecipitation reaction was demonstrated by the ability of recombinant tilapia $\mathrm{GH}$ to compete with the radioactively labeled translation product. No such competition was found after the addition of BSA. Our results demonstrate that the sea bream GH is similar in its size to other purified fish GHs and provide direct evidence for the synthesis of $\mathrm{GH}$ as a prepeptide, thus supporting the conclusions presented earlier by GH cDNA cloning. 1994 Academic Press, Inc.
\end{abstract}

Growth hormone $(\mathrm{GH})$ is a single-chain polypeptide of about $22 \mathrm{kDa}$ which is produced in the somatotrophs of the anterior part of the pituitary gland and is secreted into the vascular system. The mature hormone is processed from a precursor by removal of a short signal peptide. GH is essential for normal growth and development of all vertebrates. Considerable information exists regarding the structure of fish $\mathrm{GH}$. $\mathrm{GH}$ polypeptides have been purified and characterized from many freshwater and seawater fish species. Among them are the eel (Yamaguchi et al., 1987), chum salmon (Kawauchi and Moriyama, 1988), bonito (Noso et al., 1988), yellow tail (Kawazoe et al., 1988), tuna (Kariya et al., 1989), blue shark (Yamaguchi et al., 1989), Atlantic cod (Rand-Weaver et al., 1989, 1991), tilapia (Yamaguchi et al., 1991), and catfish (Watanabe et al., 1992). The GHs purified from the different fish appear to have a molecular weight of $21-22 \mathrm{kDa}$, as estimated from SDS-polyacrylamide gel electrophoresis.

Cloning and sequence analysis of cDNAs coding for fish pre-GHs suggested the presence of a putative signal peptide similar to mammalian pre-GH cDNAs (Seeburg et al., 1977; Martial et al., 1979; Miller et al., 1980). The putative signal peptide differs in its size among different fish GHs. Its length 
ranges from 22 amino acids (a.a.) in the cyprinids such as the common carp (Chao et al., 1989; Koren et al., 1989), the grass carp (Ho et al., 1989), and the bighead carp (Chang et al., 1992), the northern pike (Schneider et al., 1992), the salmonids [rainbow trout (Agellon et al., 1988; Rentier-Delrue et al., 1989a), chum salmon (Sekine et al., 1985), coho salmon (Nicoll et al., 1987; Gonzalez-Villasenor et al., 1988), and the Atlantic salmon (Lorens et al., 1989)], to 19 a.a. in the eel (Saito et al., 1988) and 17 a.a. in the tilapia (RentierDelrue et al., 1989b), red sea bream (Momota et al., 1988), yellow tail (Watahiki et al., 1988), tuna (Sato et al., 1988), and our own study of the gilthead sea bream (Funkenstein et al., 1991). Interestingly, the length of the putative signal peptide can be correlated with the degree of homology between the different fish GHs. Thus, the gilthead sea bream GH is highly homologous with the red sea bream, tuna, yellowtail, and tilapia $\mathrm{GH}$, and all have a putative signal peptide of 17 a.a. This group of GHs has a much lower homology with the salmonid GH, which exhibits a 22-a.a. signal peptide. For comparison, the rat, human, and bovine GH have a signal peptide of 26 amino acids (Seeburg et al., 1977; Martial et al., 1979; Miller et al., 1980).

Increased interest in the potential utilization of $\mathrm{GH}$ in fish farming prompted us to clone the GH cDNA from the gilthead sea bream (Sparus aurata), which is considered to be an economically important fish species for mariculture. We found that it codes for a polypeptide of 204 amino acids, including a putative signal peptide of 17 amino acids (Funkenstein et al., 1991). Recently, we have expressed Sparus GH in Escherichia coli (Cavari et al., 1993). In order to compare between the native $\mathrm{GH}$ and the recombinant $\mathrm{GH}$, we have purified Sparus GH from the pituitary, and the results of the purification are presented in this paper. In addition, we employed specific immunoisolation techniques, using anti-
Sparus GH antiserum, in order to isolate newly synthesized $\mathrm{GH}$ from a cell-free translation system programmed with pituitary RNA. Comparison between the GH purified from Sparus pituitaries and the GH translated by pituitary RNA suggests that $\mathrm{GH}$ is synthesized in a cell-free system as a larger prehormone, compared to the native hormone isolated from Sparus pituitaries.

\section{EXPERIMENTAL PROCEDURES}

\section{Protein Purification}

Five hundred pituitary glands were removed from $S$. aurata fish cultured in the National Center for Mariculture, Eilat, Israel, during their fast growing season, frozen immediately on dry ice, and kept at $-80^{\circ}$ until use. The glands were homogenized in a solution of 0.1 $M$ ammonium bicarbonate, $\mathrm{pH} 7.5$, containing $5 \mathrm{mM}$ EDTA and $1.5 \mathrm{mM}$ phenylmethylsulfonyl fluoride (PMSF) using a Polytron homogenizer. The homogenate was centrifuged at $25,000 \mathrm{~g}$ for $30 \mathrm{~min}$. Supernatant was recovered and the pellet was rehomogenized as above. The combined supernatant was subjected to gel filtration on a Sephadex G-100 column $(1.9 \times 100$ $\mathrm{cm}$ ) equilibrated and eluted with $0.1 M$ bicarbonate buffer, $\mathrm{pH} 8.2$, at a flow rate of $12 \mathrm{ml} / \mathrm{hr}$. Fractions of $3 \mathrm{ml}$ were collected. Fractions were combined into six groups as follows: (1) tubes $27-39$, (2) tubes $40-43$, (3) tubes 44-54, (4) tubes 55-72, (5) tubes 73-82, (6) tubes 83-101. After lyophilization, each fraction was analyzed by sodium dodecyl sulfate-polyacrylamide gel electrophoresis (SDS-PAGE) and Western blot as described below. A putative GH fraction was subjected to a reverse-phase high-performance liquid chromatography (rpHPLC) on a TSK-gel ODS $120 \mathrm{~T}$ column $(0.46 \times 25 \mathrm{~cm}$, particle size $5 \mu \mathrm{m})$, at a column temperature of $40^{\circ}$ and a flow rate of $1 \mathrm{ml} / \mathrm{min}$. Elution was performed with a linear gradient of $20-80 \%$ acetonitrile containing $0.1 \%$ TFA for $60 \mathrm{~min}$. Proteins were monitored by measuring the absorbance at $220 \mathrm{~nm}$. Fractions were analyzed by SDS-PAGE and Western blot as described below.

\section{Electrophoresis and Western Blot}

Fractions from the Sephadex G-100 column and from the rpHPLC were analyzed by SDS-PAGE $(12 \%)$. Proteins were stained with $0.2 \%$ Coomassie blue R-250. The gilthead sea bream GH was identified by Western blot. Proteins were electrotransferred to nitrocellulose membranes (Towbin et al., 1979) and reacted with a 2000 dilution of specific antiserum raised against bonito (Katsuonus pelamis) GH (Noso et al., 1988), and then incubated with biotinylated goat 
anti-rabbit IgG (Vector Labs, Burlingame, CA). Detection was accomplished by the avidin-biotin reagent (Vectastain ABC kit, Vector Labs) and 3,3diaminobenzidine in $\mathrm{H}_{2} \mathrm{O}_{2}$.

\section{RNA Isolation and Cell-Free Translation}

Total RNA was isolated from pituitaries of S. aurata fjsh during their fast growing season by the rapid method of Chomczynski and Sacchi (1987). RNA was translated in a commercially available rabbit reticulocyte lysate system (New England Nuclear) in a total volume of $25 \mu \mathrm{l}$. Incubations were carried out at $37^{\circ}$ for $60 \mathrm{~min}$. The incorporation of $\left[{ }^{35} \mathrm{~S}\right]$ methionine into TCA-precipitable protein was measured in order to assay for translational efficiency.

\section{Immunoprecipitation and Electrophoresis}

After the translation reaction was terminated, samples were diluted with $1 / 5 \mathrm{vol}$ of $50 \mathrm{~m} M$ methionine in phosphate-buffered saline, vortexed, and then diluted again with an equal volume of $10 \%$ SDS. Samples were next heated at $100^{\circ}$ for 2 min and diluted 1:10 with phosphate-buffered saline containing $1 \mathrm{~m} M$ EDTA, $0.5 \% \mathrm{NP}-40$, and $10 \mathrm{~m} M$ methionine. Immunoisolation of $\mathrm{GH}$ from translation products was carried out by a modification of the procedure described by Ivarie and Jones (1979) using Staphylococcus aureus cell membranes (Pansorbin, Calbiochem). The diluted translation products were first incubated for $1 \mathrm{hr}$ at room temperature with $30 \mu \mathrm{l}$ of washed Pansorbin (10\% suspension). After a 5 -min centrifugation at $13,000 \mathrm{~g}$, the supernatant was removed and incubated with $2 \mu l$ nonimmune rabbit serum for $45 \mathrm{~min}$. This was followed by the addition of $30 \mu$ of washed Pansorbin, and incubation was continued for an additional $30 \mathrm{~min}$ at room temperature. After centrifugation, the supernatant was incubated overnight at $4^{\circ}$ with specific antiserum raised against $S$. aurata $G H$ (Le Bail et al., submitted for publication), or with antiserum raised against recombinant tilapia GH. Thirty microliters of Pansorbin was then added, and the samples were incubated at room temperature for $10 \mathrm{~min}$ and then centrifuged as above. At this point the pellet was recovered and sus. pended in $200 \mu$ of phosphate-buffered saline containing $0.1 \%$ SDS, $0.5 \%$ NP.40, $10 \mathrm{~m} M$ methionine, and 1 $\mathrm{m} M$ EDTA. This suspension was centrifuged through $1 \mathrm{ml}$ of $1.5 M$ sucrose. The pellet was recovered and washed with the above saline solution by suspension and centrifugation 3-4 times. The pellet was suspended in $30 \mu \mathrm{l}$ of Laemmli electrophoresis sample buffer (Laemmli, 1970) containing 1\% $\beta$-mercaptoethanol (or alternatively without $\beta$-mercaptoethanol) and boiled for $3 \mathrm{~min}$ to dissociate the immunoisolated protein from the immune IgG and Pansorbin. Following centrifugation, the supernatant was analyzed by SDSPAGE utilizing 3 to $15 \%$ gradient gels. The gels were dried and subjected to autoradiography. Alignment between the Coomassie-stained gel and the autoradiogram was done by including $\left[{ }^{35} \mathrm{~S}\right]$ methionine dots on the 3 MM paper on which the gel was dried.

\section{Source of Hormones and Antisera}

Recombinant tilapia growth hormone $(\mathrm{rtGH})$ was kindly provided by J. Smal (Eurogentec, Liege, Belgium). Antiserum against Sparus $\mathrm{GH}$ was prepared by P.-Y. LeBail (Rennes, France); antisera against bonito GH was prepared in H. Kawauchi's lab (Noso et al., 1988 ) and antisera against recombinant tilapia $\mathrm{GH}$ was prepared by B. Levavi-Sivan and P. Melamed.

The specificity of the anti-tilapia $\mathrm{GH}(\mathrm{tiGH})$ was determined by examining the cross reaction of the radioimmunoassay for tiGH with recombinant tilapia prolactin (tiPRL; Rentier-Delrue, Liege, Belgium) and recombinant common carp GH (cGH; Gertler, Rehovot, Israel). In addition, the ability of the antiserum to bind substances in pituitary extracts of the common carp (Cyprinus carpio) and the gilthead sea bream ( $S$. aurata) was compared to its affinity for the tilapia pituitary extract (tiPE). The sensitivity of this assay was $0.52 \mathrm{ng} / \mathrm{ml}$.

\section{RESULTS}

\section{Isolation of Sparus aurata $G H$}

Sparus aurata GH was isolated from pituitary glands of fast growing fish. Gel filtration on Sephadex G-100 is shown in Fig. 1. Six fractions were pooled, as outlined in the figure. SDS-PAGE of these fractions revealed that fraction 4 contained a protein which reacted positively in a Western blot with anti-bonito GH (Figs. 2A,2B). Fraction 4 was further purified by rpHPLC (Fig. 3). SDS-PAGE analysis of the fractions, illustrated in Fig. 4A, revealed that fraction 16 contained a protein that reacted positively in a Western blot with anti-bonito GH (Fig. 4B). The electrophoretic mobility of the purified protein from fraction 16 was compared to that of recombinant tilapia $\mathrm{GH}$ (Fig. 5, lanes 2, 6 and lanes 3, 7, respectively). The molecular weight of Sparus GH was estimated to be $21 \mathrm{kDa}$ under nonreduced conditions and $22 \mathrm{kDa}$ in the presence of $1 \% \beta$-mercaptoethanol (Fig. 5, lanes 2,6). 


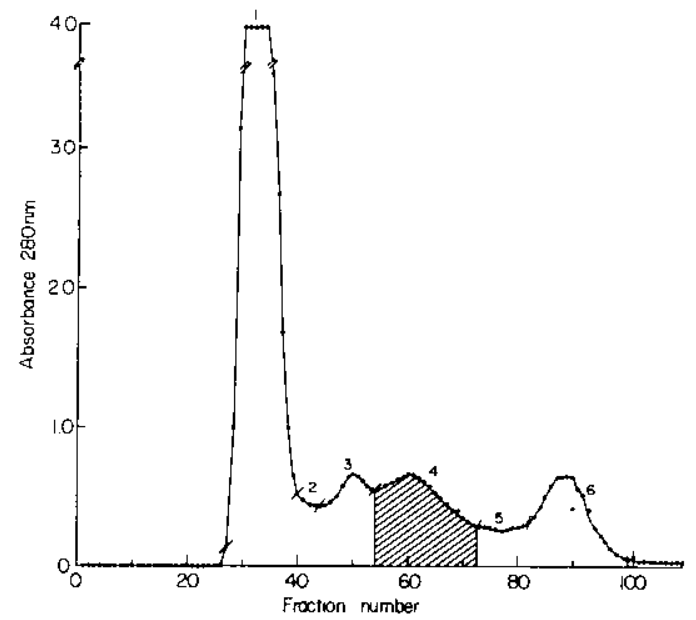

FIG. 1. Gel filtration of Sparus aurata pituitary extracts on Sephadex G-100. Elution with $0.1 \mathrm{M}$ ammonium bicarbonate buffer, $\mathrm{pH} 8.2$; column size: $1.9 \times$ $100 \mathrm{~cm}$; fraction size: $3 \mathrm{ml} / 15 \mathrm{~min}$. Fraction G4 was subjected to rpHPLC chromatography.

\section{Cell-Free Synthesis of Sparus GH}

In a cell-free translation system programmed with pituitary total RNA, GH was synthesized as a larger prehormone, compared to the native hormone isolated from



FIG. 3. Reversed-phase high-performance liquid chromatography of G4 on a TSK-gel ODS-120T column with linear gradient of $20-80 \%$ acetonitrile in $0.1 \%$ trifluoroacetic acid at a flow rate of $1 \mathrm{ml} / \mathrm{min}$.

(B)

\section{(A)}



FiG. 2. Analysis of fractions collected from Sephadex G-100 chromatography by SDS-PAGE (A) and Western blot (B). S, standard molecular weight markers. The numbers designate pooled fractions recovered from Sephadex G-100 column. 
(B)



$211615131210 \mathrm{~S}$

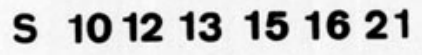

FIG. 4. Analysis of fractions collected from rpHPLC chromatography by SDS-PAGE (A) and Western blot (B). S, standard molecular weight markers. The numbers correspond to the fraction numbers which are shown in Fig. 3.

Sparus pituitaries (compare Fig. 5, lanes 4, 8 to lanes 2,6 ). The molecular weight of the precursor form was estimated to be 27-28 $\mathrm{kDa}$ when electrophoresed in SDS-PAGE under reduced conditions and $26-27 \mathrm{kDa}$

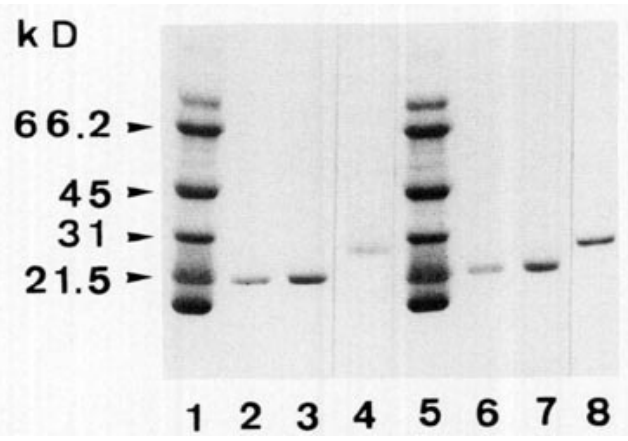

FIG. 5. Electrophoretic comparison between newly synthesized GH immunoisolated from a cell-free system and native GH. Coomassie blue stain of molecular weight standards (lanes 1,5), purified Sparus GH (lanes 2, 6), and recombinant tilapia GH (lanes 3, 7). Lanes 4 and 8 , autoradiogram of newly synthesized GH immunoisolated from a cell-free translation system programmed with RNA prepared from pituitary glands using anti-Sparus GH. Lanes 1-4 were electrophoresed under nonreduced conditions. Lanes 5-8 were electrophorsed in the presence of $1 \% \beta$-mercaptoethanol. under nonreduced conditions. To confirm whether the precipitated protein from cellfree translation was indeed $\mathrm{GH}$, immunoisolation was conducted in the presence of excess recombinant tilapia $\mathrm{GH}$ or BSA for control. While tilapia GH almost completely displaced the radiolabeled immunoisolate from in vitro translation products



F1G. 6. Specificity of immunoisolation reaction. Coomassie blue stain of molecular weight standards (lane 1), Sparus GH (lane 2), or recombinant tilapia GH (lane 3). Lane 4, autoradiogram of newly synthesized $\mathrm{GH}$ immunoisolated from a cell-free translation system programmed with pituitary RNA using antiSparus GH. Lanes 5 and 6, same as lane 4, except that immunoisolation was conducted in the presence of excess tilapia GH or BSA, respectively. 
(Fig. 6, lane 5), BSA did not compete for the radiolabeled protein (Fig. 6, lane 6). Due to limitation in the amounts available of purified Sparus GH, competition was not performed using Sparus GH.

Since recombinant tilapia GH successfully competed with radiolabeled Sparus GH in the immunoisolation reaction, the ability of antiserum against tilapia $\mathrm{GH}$ to immunoisolate Sparus GH was tested. Initially, the specificity of these antibodies was characterized. The displacement curve obtained with the pituitary extract of $S$. aurata was parallel to that of the standard curve of tiGH between $0.002 \mathrm{pit} / \mathrm{ml}$ and $0.02 \mathrm{pit} / \mathrm{ml}$, while the pituitary extract of the carp did not (Fig. 7). The cGH was not able to displace the tiGH from its binding to the anti-tiGH, while the tiPRL had succeeded in displacing the tiGH only at a pharmacologic concentration of $10 \mu \mathrm{g} / \mathrm{ml}$ (Fig. 7). Similar results to those obtained with anti-Sparus $\mathrm{GH}$ were found when anti- recombinant tilapia $\mathrm{GH}$ was used in the immunoprecipitation reaction (compare Fig. 8 , lanes 3 and 6). A competition experiment showed the ability of recombinant tilapia $\mathrm{GH}$ to displace the radiolabeled immunoisolate, while BSA failed (compare Fig. 8 , lanes 4 and 5, respectively). The upper faint band detected in all immunoisolations is probably a nonspecific band which is bound and comigrates with the large fragment of IgG. The lower faint band seen in Fig. 8 is probably the result of incomplete reduction of the pre-GH.

\section{DISCUSSION}

In the present study, $S$. aurata $\mathrm{GH}$ was purified from pituitaries of fast growing fish. Its molecular weight in SDS-PAGE gel electrophoresis under reduced conditions was estimated to be $22 \mathrm{kDa}$, which is in agreement with the molecular weight of other fish GHs. In the absence of homolo-

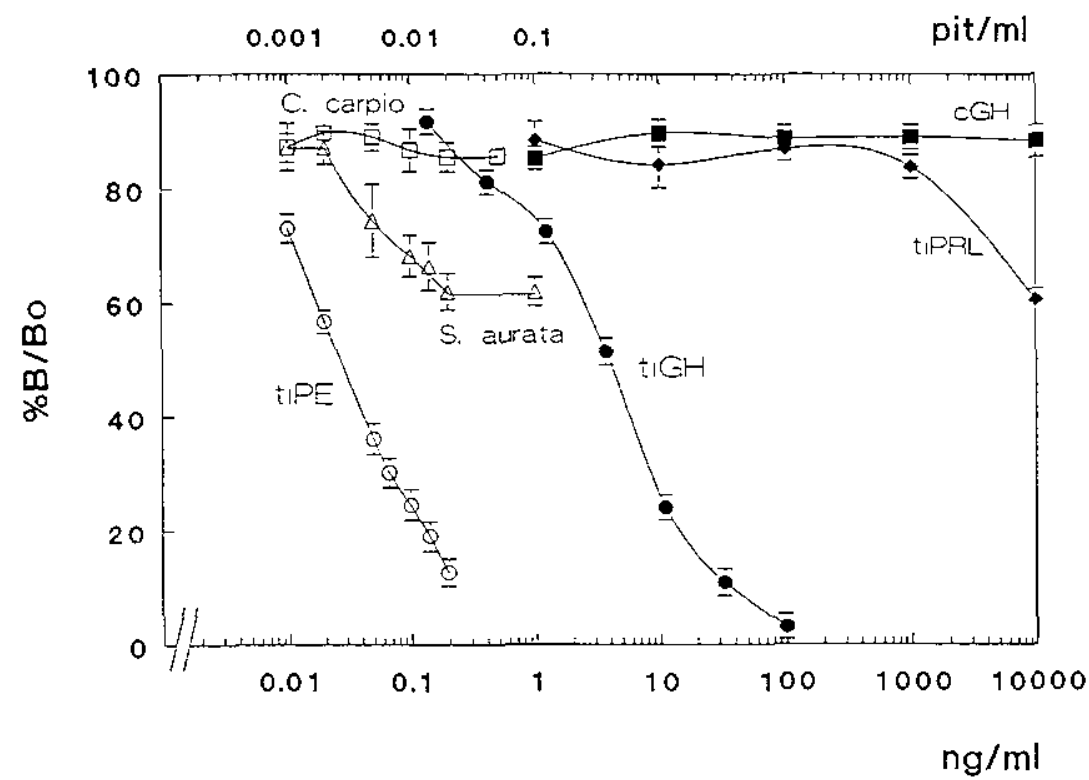

FIG. 7. Cross-reaction of substances in pituitary extracts of tilapia (tiPE; $O$ ), Sparus aurata $(\Delta)$, and Cyprinus carpio ( $\square$ ), and the recombinant piscine pituitary hormones: carp growth hormone (cGH; ) and tilapia prolactin (tiPRL; ) in the radioimmunoassay for tilapia GH (tiGH; ). Binding is expressed as $\%$ of total binding; the lower $x$ axis refers to the concentration $(\mathrm{ng} / \mathrm{ml})$ of the pituitary hormones (closed symbols), and the top $x$ axis refers to pituitary equivalents per milliliter (open symbols). 




FIG. 8. Comparison between newly synthesized GH immunoisolated from cell-free translation of pituitary RNA using antiserum against Sparus GH or tilapia GH. Coomassie blue stain of molecular weight standards (lane 1), recombinant tilapia GH (lane 2). Lanes 3 and 6 , autoradiogram of newly synthesized GH immunoisolated from a cell-free translation system programmed with pituitary RNA using anti-tilapia GH (lane 3) or anti-Sparus GH (lane 6). Lanes 4 and 5, same as lane 3 , except that immunoisolation was conducted in the presence of excess tilapia GH or BSA, respectively.

gous antibodies at the time of purification, the purification steps were monitored by Western blot using anti-bonito $\mathrm{GH}$ which was found to cross-react with Sparus GH.

The GH synthesized in a cell-free translation system was found to be a larger prehormone. Its molecular weight was estimated to be $27-28 \mathrm{kDa}$ in SDS-PAGE, under reduced conditions, and $26-27 \mathrm{kDa}$ under nonreduced conditions. Based on the deduced amino acid sequence, the molecular weight of Sparus pre-GH was calculated to be 26,296 . It is well established that peptide hormones, in analogy to other secreted proteins, are synthesized in the rough endoplasmic reticulum as prehormones which undergo cleavage of the signal peptide prior to being secreted (Walter et al., 1984). However, using a specific immunoisolation technique, this is the first direct evidence for the synthesis of fish $\mathrm{GH}$ as a prehormone. The reticulocyte system used for cell-free translation is not able to glycosylate the translation product. Thus, the higher molecular weight of the product is not due to sugars which might alter the electrophoretic mobility. The $\mathrm{N}$-terminal por- tion (signal peptide) of the precursor is thought to be involved in its attachment to the endoplasmic reticulum membranes, a process essential for hormone maturation and secretion. Accordingly, rat and bovine pre-GH were found to be $25 \mathrm{kDa}$ (Seeburg et al., 1977; Miller et al., 1980) when translated in vitro and immunoprecipitated by appropriate antisera, about $3 \mathrm{kDa}$ larger than the mature hormone. Similarly, human pre-GH translated by mRNA isolated from $\mathrm{GH}$-producing tumors was found to be a 24-kDa precursor form (Martial et al., 1979). Duck pituitary RNA directed the synthesis of a protein of $25 \mathrm{kDa}$ (Chen et al., 1988).

The characterization of the anti-Sparus GH used in this study was described elsewhere (LeBail et al., submitted for publication). It did not cross-react in an RIA with mammalian or recombinant tilapia prolactin. The specificity of the immunoprecipitation reaction was demonstrated in the present study by the ability of excess recombinant tilapia $\mathrm{GH}$ to compete with the radioactively labeled translation product. No such reaction was found when BSA was added. In the absence of sufficient amounts of Sparus GH, competition experiments were performed using only tilapia GH. Tilapia GH has a homology of $85 \%$ with sea bream GH (Yamaguchi et al., 1991). It was found (Le Bail, unpublished results) that purified sea beam GH had a substantial cross reactivity with tilapia $\mathrm{GH}$ in an RIA using anti-tilapia GH. Similarly, we demonstrate in this study that extracts of Sparus pituitaries are able to displace tilapia GH in RIA using a different preparation of antitilapia GH. Taken together, these findings support our present results regarding the ability of recombinant tilapia $\mathrm{GH}$ to compete efficiently with sea bream $\mathrm{GH}$ in the immunoisolation reaction.

Characterization of anti-tilapia $\mathrm{GH}$ used in this study revealed no cross-reactivity with carp GH or recombinant tilapia prolactin. As mentioned earlier, extracts from 
Sparus pituitaries displaced labeled tilapia GH in a manner parallel to that of tilapia GH itself (see Fig. 7). This antiserum efficiently immunoprecipitated Sparus pre-GH from translation products directed by Sparus pituitary RNA, indicating substantial cross reactivity between the anti-tilapia GH and Sparus GH.

Recently, we have cloned the gilthead sea bream ( $S$. aurata) GH cDNA and showed that it encodes for a polypeptide of 204 amino acids, including a putative signal peptide of 17 amino acids (Funkenstein et al., 1991). Using this cDNA as a radioactive probe, we have shown previously that Sparus larvae collected 6 days after hatching express high levels of GH mRNA (Funkenstein et al., 1992). Using antiserum against Sparus $\mathrm{GH}$, purified in the course of this study, we are currently studying the presence of immunoreactive $\mathrm{GH}$ in extracts of whole Sparus larvae. This question is of particular importance since we have found recently that IGF-I, which is believed to be a mediator of $\mathrm{GH}$ action, is expressed very early during larval development (Cohen et al., unpublished results). The immunoisolation reaction used in this study will be used in future studies to test the ability of poly $\left(\mathrm{A}^{+}\right)$RNA prepared from $S$. aurata larvae to direct the synthesis of $\mathrm{GH}$ peptide.

\section{ACKNOWLEDGMENTS}

We are grateful to Dr. J. Smal (Eurogentec, Belgium) for the recombinant tilapia GH. We also thank Keren Diskin for skilled editorial assistance. This work was supported in part by the United StatesIsrael Binational Agricultural Research and Development Fund (BARD, Project IS-1973-91).

\section{REFERENCES}

Agellon, L. B., Davies, S. L., Lin, C. M., Chen, T. T., and Powers, D. A. (1988). Rainbow trout has two genes for growth hormone. Mol. Reprod. Dev. 1, 11-17.

Cavari, B., Funkenstein, B., Chen, T. T., GonzalezVillasenor, L. I. and Schartl, M. (1993). Effect of growth hormone on the growth rate of the gilthead sea bream (Sparus aurata), and use of different constructs for production of transgenic fish. Aquaculture 111, 189-197.

Chang, Y. S., Liu, C. S., Huang, F. L., and Lo, T. B. (1992). The primary structures of growth hormones of three cyprinid species: Big head carp, silver carp and grass carp. Gen. Comp. Endocrinol. 87, 385-393.

Chao, S.-C., Pan, F.-M., and Chang, W.-C. (1989). Purification of carp growth hormone and cloning of the complementary DNA. Biochem. Biophys. Acta 1007, 233-236.

Chen, H. T., Pan, F. M., and Chang, W. C. (1988). Purification of duck growth hormone and cloning of the complementary DNA. Bioch. Biophys. Acta 949, 247-251.

Chomczynski, P., and Sacchi, N. (1987). Single-step method of RNA isolation by acid guanidinium thiocyanate-phenol-chloroform extraction. Anal. Biochem. 162, 156-159.

Funkenstein, B., Chen, T. T., Powers, D. A., and Cavari, B. (1991). Cloning and sequencing of the gilthead seabream (Sparus aurata) growth hormoneencoding cDNA. Gene 103, 243-247.

Funkenstein, B., Tandler, A., and Cavari, B. (1992). Developmental expression of the growth hormone gene in the gilthead sea bream Sparus aurata. Mol. Cell. Endocrinol. 87, R7-R9.

Gonzalez-Villasenor, L. I., Zhang, P., Chen, T. T., and Powers, D. A. (1988). Molecular cloning and sequencing of coho salmon growth hormone cDNA. Gene 65, 239-246.

Ho, W. K. K., Tsang, W. H., and Dias, N. P. (1989). Cloning of the grass carp growth hormone cDNA. Biochem. Biophys. Res. Commun. 161, 12301243.

Ivarie, R. D., and Jones, P. P. (1979). A rapid sensitive assay for specific protein synthesis in cells and in cell-free translations: Use of Staphylococcus aureus as an absorbent for immune complexes. Anal. Biochem. 97, 24-35.

Kariya, Y., Sato, N., Kawazoe, I., Kimura, S., Miyazaki, N., Nonaka, M., and Kawauchi, H. (1989). Isolation and characterization of growth hormone from a marine fish, tuna (Thunnus albacares). Agric. Biol. Chem. 53, 1679-1687.

Kawauchi, H., and Moriyama, S. (1988). Chum salmon growth hormone: Isolation and effects on growth of juvenile rainbow trout. In "New and Innovative Advances in Biology/Engineering with Potential for Use in Aquaculture" (Sparks, A. K., Ed.), NOAA Technical Report NMFS 70, National Marine Fisheries Service, Seattle, WA.

Kawazoe, I., Noso, T., Kuriyama, S., Akasaka, A., and Kawauchi, H. (1988). Isolation and characterization of growth hormone from yellowtail $\mathrm{Se}$ riola quinequeradiata. Nippon Swisan Gakkaishi 54, 393-399. 
Koren, Y., Sarid, S., Ber, R., and Daniel, V. (1989). Carp growth hormone: Molecular cloning and sequencing of cDNA. Gene 77, 309-315.

Laemmli, U. K. (1970). Cleavage of structural protein during the assembly of the bacteriophage T4. $\mathrm{Na}$ ture 227, 680-685.

Lorens, J., Nerland, A. H., Male, R., Lossius, I., Telle, W., and Totland, G. (1989). The nucleotide sequence of Atlantic salmon growth hormone cDNA. Nucleic Acids Res. 17, 2352.

Martial, J. A., Hallewell, R. A., Baxter, J. D., and Goodman, H. M. (1979). Human growth hormone: Complementary DNA cloning and expression in bacteria. Science 205, 602-607.

Miller, W. L., Martial, J. A., and Baxter, J. D. (1980). Molecular cloning of DNA complementary to bovine growth hormone mRNA. J. Biol. Chem. 255, 7521-7524.

Momota, H., Kosugi, R., Hiramatsu, H., Ohgai, H., Hara, A., and Ishioka, H. (1988). Nucleotide sequence of cDNA encoding the pregrowth hormone of red seabream (Pagrus major). Nucleic Acids Res. 16, 3107.

Nicoll, C. S., Steiny, S. S., King, D. S., Nishioka, R. S., Mayer, G. L., Eberhardt, N. L., Baxter, J. D., Yamanaka, M. K., Miller, J. A., Sckilkamer, J. J., Schilling, J. W., and Johnson, L. K. (1987). The primary structure of coho salmon growth hormone and its cDNA. Gen. Comp. Endocrinol. 68, 387-399.

Noso, T., Yasuda, A., Kawazoe, 1., Takehara, H., Takahasi, A., Sakai, K., and Kawauchi, H. (1988). Isolation and characterization of growth hormone from a marine fish, bonito (Katsuwonus pelamis). Int. J. Peptide Protein Res. 32, 579-589.

Rand-Weaver, M., Walther, B. T., and Kawauchi, H. (1989). Isolation and characterization of growth hormone from the Atlantic cod (Gadus morhua). Gen. Comp. Endocrinol. 73, 260-269.

Rand-Weaver, M., Noso, T., and Kawauchi, H. (1991). The complete amino acid sequences of two variants of growth hormone from Atlantic cod (Gadus morhua). Gen. Comp. Endocrinol. 81, 3950.

Rentier-Delrue, F., Swennen, D., Mercier, L., Lion, M., Benrubi, O., and Martial, J. A. (1989a). Molecular cloning and characterization of two forms of trout growth hormone cDNA: Expression and secretion of tGHII by E. coli. DNA 8, 109-117.

Rentier-Delrue, F., Swennen, D., Philippart, J. C., L'hoir, C., Lion, M. Benrubi, O., and Martial, J. A. (1989b). Tilapia growth hormone: Molecular cloning of cDNA and expression of E. coli. DNA 8, 271-278.

Saito, A., Sekine, S., Komatsu, Y., Sato, M., Hirano,
T., and Itoh, S. (1988). Molecular cloning of eel growth hormone cDNA and its expression in Escherichia coli. Gene 73, 545-551.

Sato, N., Watanabe, K., Murata, K., Sakaguchi, M., Kariya, Y., Kimura, S., Nonaka, M., and Kimura, A. (1988). Molecular cloning and nucleotide sequence of tuna growth hormone cDNA. Biochem. Biophys. Acta 949, 35-42.

Schneider, J. F., Myster, S. H., Hackett, P. B., Guise, K. S., and Faras, A. J. (1992). Molecular cloning and sequence analysis of the cDNA for northern pike (Esox lucius) growth hormone. Mol. Mar. Biol. Biotech. 1, 106-112.

Seeburg, P. H., Shine, J., Martial, J. A., Baxter, J. D., and Goodman, H. M. (1977). Nucleotide sequence and amplification in bacteria of structural gene for rat growth hormone. Nature 270, 486-494.

Sekine, S., Mizukami, T., Nishi, T., Kuwana, Y., Saito, A., Sato, M., Itoh, S., and Kawauchi, H. (1985). Cloning and expression of cDNA for salmon growth hormone in Escherichia coli. Proc. Natl. Acad. Sci. USA 82, 4306-4310.

Towbin, H., Staehelin, T., and Gordon, J. (1979). Electrophoretic transfer of proteins from polyacrylamide gels to nitrocellulose sheets: Procedure and some applications. Proc. Natl. Acad. Sci. USA 76, 4350-4354.

Walter, L., Gilmore, R., and Blobel, G. (1984). Protein translocation across the endoplasmic reticulum. Cell 38, 5-8.

Watahiki, M., Tanaka, M., Masuda, N., Yamakawa, M., Yoneda, Y., and Nakashima, K. (1988). cDNA cloning and primary structure of yellow tail (Seriola quinquerodiata) pregrowth hormone. Gen. Comp. Endocrinol. 70, 401-406.

Watanabe, K., Igarashi, A., Noso, T., Chen, T. T., Dunham, R. A., and Kawauchi, H. (1992). Chemical identification of catfish growth hormone and prolactin. Mol. Mar. Biol. Biotech. 1, 239-249.

Yamaguchi, K., Yasuda, A., Kishida, M., Hirano, T., Sano, H., and Kawauchi, H. (1987). Primary structure of eel (Anguilla japonica) growth hormone. Gen. Comp. Endocrinol. 66, 447-453.

Yamaguchi, K., Yasuda, A., Lewis, U. J., Yokoo, Y., and Kawauchi, H. (1989). The complete amino acid sequence of growth hormone of an elasmobranch, the blue shark (Prionace glauca). Gen. Comp. Endocrinol. 73, 252-259.

Yamaguchi, K., King, D. S., Specker, J. L., Nishioka, R. S., Hirano, T., and Bern, H. A. (1991). Amino acid sequence of growth hormone isolated from medium of incubated pituitary glands of tilapia (Oreochromis mossambicus). Gen. Comp. Endocrinol. 81, 323-331. 